\title{
Effect of Combined Aerobic Training and Inspiratory Muscle Trainer on Ventilatory Functions in Hemodialysis Patients
}

\author{
ZAHRA M. HASSAN, Ph.D. ${ }^{1}$; HEBA A. BAHEY EL-DEEN, Ph.D. ${ }^{2}$; SAHIER O. EL-KHASHAB, M.D. ${ }^{3}$ and \\ HEBA A. YUSUF, M.Sc. ${ }^{4}$ \\ The Department of Physical Therapy for Cardiovascular/Respiratory Disorders \& Geriatrics, Faculty of Physical Therapy, \\ Cairo University ${ }^{1}$, The Department of Physical Therapy for Surgical Disorders, Faculty of Physical Therapy, \\ Misr University for Science \& Technology ${ }^{2}$, The Department of Internal Medicine \& Nephrology, Faculty of Medicine, \\ Cairo University ${ }^{3}$ and The Department of Physical Therapy for Cardiovascular/Respiratory Disorders \& Geriatrics, \\ Misr University for Science \& Technology ${ }^{4}$, Egypt
}

\begin{abstract}
Background: Decreased respiratory muscle strength is associated with decreased pulmonary functions and considered as a serious mortality risk in patients on hemodialysis $[\mathbf{1 , 2}]$

Aim of Study: This study was conducted to compare between the effect of 12 weeks of supervised aerobic training program combined with Inspiratory Muscle Trainer (IMT) and using Inspiratory Muscle Trainer (IMT) alone on ventilatory functions in hemodialysis patients (HD). Pulmonary functions were measured by electronic spirometer including (Forced Vital Capacity (FVC), forced expiratory volume in one second (FEV 1), FEV1/FVC, Peak Expiratory Flow (PEF) and Maximum Voluntary Ventilation (MMV) in HD patients respectively.
\end{abstract}

Subjects and Methods: Thirty patients from both sexes participated in the study. They were divided randomly into two groups of equal number. Group (A) received combined IMT with supervised program of aerobic training in the form of leg pedaling exercises, while Group (B) received IMT alone.

Results: The results of this study revealed significant improvement in all measured values of pulmonary functions in both groups. Surprisingly, it was more significant in favor of group B.

Conclusion: It was concluded that either a combined IMT with supervised program of aerobic training or IMT alone for 12 weeks, both have significant improvement regarding pulmonary functions in hemodialysis patients, while it was more significant with IMT alone.

Key Words: Hemodialysis - Inspiratory muscle trainer Aerobic training - Leg pedaling - Pulmonary function.

Correspondence to: Dr. Zahra M. Hassan, The Department of Physical Therapy for Cardiovascular/ Respiratory Disorders \& Geriatrics, Faculty of Physical Therapy, Cairo University, Egypt

\section{Introduction}

CHRONIC Kidney Disease (CKD) is defined as progressive loss in renal function over a period of months or years. In Egypt, the estimated annual incidence of End Stage Renal Disease (ESRD) is around 74 per million and the total prevalence of patients who need hemodialysis as a replacement therapy is 264 per million [3]

Patients with end-stage renal disease, especially who undergo hemodialysis have various pulmonary complications either from dialysis process or from the disease impact itself [4-7]. Such complications as accumulation of uremic toxins (urea and creatinine), volume overload from fluid retention and anemia from lack of erythropoietin production. All of which may lead to a reduction in respiratory muscle strength and consequently pulmonary functions [8-11].

It has been observed that there was defective protein metabolism in those treated with regular hemodialysis. The impaired protein synthesis and protein degradation may lead togeneralized muscle atrophy which in turn results in significant reduction of strength and ability to generate force [12-15]

Regular physical exercises as that in the form of intradialytic cycling ergometer may lead to improved peak oxygen consumption, maintenance of physical endurance, functional independence $[16,17]$ and the overall quality of life in hemodialytic patients $[18,19]$

Inspiratory Muscle Trainer (IMT) is a recent effective method to enhance respiratory muscles strength [20]. Pellizzaro,showed that respiratory 
muscle training by using IMT program for 10 weeks during dialysis sessions has a significant improvement in both maximum inspiratory pressure (PImax) and maximum expiratory pressure (PEmax) [21]. According to De Medeiros et al., the percentage of type I fibers and size of type II fibers in respiratory muscles of COPD patients had increased following the application of inspiratory muscle trainer [22]. Therefore, strengthening of respiratory muscles by using threshold inspiratory muscle trainer for those patients may enhance the function of the pulmonary system entirely [23]

From the above findings, this study aims to evaluate the combined effect of performing both aerobic exercise training and inspiratory muscle trainer on pulmonary functions in hemodialytic patients.

\section{Subjects and Methods}

Thirty clinically stable patients from both sexes (14 males and 16 females) were enrolled into the study and randomly allocated into two groups of equal number. Group A was composed of fifteen patients received supervised program of aerobic training in the form of leg pedaling exercises and Inspiratory Muscle Trainer (IMT) in addition to standard medical treatment. Group B was composed of fifteen patients received inspiratory muscle trainer and standard medical treatment.

Inclusion criteria: Patients who had the following criteria were included in the study: Patients who have sufficient level of cognition and ability to understand instructions. All of them had vascular access through an arterio-venous fistula. Their ages ranged from 45 to 65 years old. They received regular hemodialysis sessions at least three months with each session lasting 4 hours at a Hemodialysis Unit of Al-Kasr Al-Aini Hospital, at Faculty of Medicine, Cairo University, Egypt. A specialized physician initially examined all recruited patients.

Exclusion criteria: Patients who had the following criteria were excluded from the study such as patients with chronic chest, cardiac, neurological disease or who had a current smoking habit, which may interfere with exercise training. All patients, regardless of their health status were allowed to discontinue the training program and withdraw from the study at any time.

This study was carried out according to the principles of the Declaration of Helsinki 1975, revised Hong Kong 1989 and was approved by Human Research Ethics Committee of the Faculty of Physical Therapy, Cairo University.
Material and Methods:

\section{For evaluation:}

Electronic Spirometer: Measuring pulmonary function test by an electronic Spirometer (Model -Schiller AG, CH6304) was used to measure Forced Vital Capacity (FVC), Forced Expiratory Volume in one second (FEV 1), FVC/FEV 1 ratio, Peak Expiratory Flow (PEF) based on the total pulmonary capacity and Maximum Voluntary Ventilation (MVV). Guidelines of the Pulmonary Function Tests were used with all patients in the study $[24,25]$ MVV was calculated as approximately equal to the FEV 1 X 40 [26]. Measurements for all patients were performed once before initiating the study and another after completion of 12 weeks of training program.

\section{For treatment:}

- Aerobic training program: Patients in group A were assigned to perform a supervised training program in the form of leg pedaling exercises using (grand easy exerciser 111-China) in a semi-supine position and during the first two hours of hemodialysis procedure to avoid dialysis hypotension episodes. Program extended over a period of 3 months, three times a week. Training sessions was performed under direct supervision of a physiotherapist. Each training session consisted of three phases [27]. Phase one-warm-up (5 minutes)-free active exercises of the lower extremities. Phase two-the conditioning phase (20 minutes)-exercise on a leg pedaling (the speed was set at one cycle per second at $0.5 \mathrm{~km} / \mathrm{h})$. Phase three-cool-down $(5$ minutes)-free active exercises of the lower extremities. Training duration was gradually increased from $10 \mathrm{~min}$ in the first session to $30 \mathrm{~min}$ in the subsequent sessions $[\mathbf{1 9 , 2 8 , 2 9 ]}$.

The prescription of exercise intensity was based on Borg's Perceived Exertion Scale [29]. According to this scale, patients assign a score to the intensity of fatigue that varies from 6 to 20 points. During leg pedaling, patients were asked about the score they would assign to their fatigue every 5 minutes. The pedaling load was maintained to achieve an intensity of stress enough to determine a score of fatigue between 11 and 13 points (i.e. less than a little tired), which corresponds to an exercise of "mild" intensity to "quite hard" in this scale. If changes were noted, exercise was discontinued for $10 \mathrm{~min}$. After which, if symptoms resolved, patients were allowed to resume. If symptoms did not resolve then no more exercise was permitted for that day. Prolongation of a single training session and change in intensity depend on patient's reaction to physical effort. 
- Termination of exercises during the training session took place in the following cases: Inability to maintain the recommended rate of pedaling, occurrence of retrosternal, muscular, articular pain, occurrence of nausea, dizziness, muscle cramps; or patient's request (malaise, fatigue) [27] .

- Inspiratory muscle training program:Inspiratory muscle training program was conducted byThreshold IMT (HS 730-010) manufactured for Respiratory Drug Delivery, UK, Ltd with a dial selector used to detect the resistance level. The device contains a valve to ensure consistent resistance regardless of the air flow that trains respiratory muscles. Each patient breathes through a separate mouthpiece through attach the mouthpiece firmly and put the nose clip and inhale deeply through the mouth piece to generate an inspiratory pressure greater than the indicated presetting threshold pressure to compress the spring and open the valve. The intensity was 30\% from 10 Repetition Max with duration ranged from 20-30 minutes [30]. The inspiratory muscle training session was started after 10 minutes of resting from aerobic training in group A while in group B it was started within the first half hour of hemodialysis session.

\section{For statistical analysis:}

For descriptive statistics, mean and standard deviations were calculated for all variables. Bar graphs were used to display the means of all variables pre and post-treatment. For analytical statistics, paired $t$-test was used to test if there is a significant difference between pre and post means of the measured variables in the same group. Independent samples $t$-test was used to test if there is a significant difference between the means of pre and post-treatment of the two groups. The Statistical program (SPSS) Version 16.0 was used in statistical analysis. The significance level was set at $95 \%$ so that a test is considered significant if $p$-value $<0.05$.

\section{Results}

As shown in (Table 1), comparing the general characteristics of the subjects of both groups revealed that there was no significant difference between both groups regarding the mean values of age, weight, height, or BMI.There was no significant difference in the mean values of ventilatory functions (FVC, FEV $1, \mathrm{FEV}_{1} / \mathrm{FVC}, \mathrm{PEF}$ and MVV) between group A and B pre-treatment $(p>0.05)$.

Table (2) shows results of the mean \pm SD values of group A for all measured variables (FVC, FEV 1 , $\mathrm{FEV}_{1} / \mathrm{FVC}, \mathrm{FEF}$ and MVV) the pre-treatment mean values were $47.07 \pm 16.37 \%, 44.85 \pm 15.98 \%, 100 \pm$ $17.72 \%, 29.78 \pm 12 \%$ and $48.65 \pm 18.53 \%$ respectively). While post-treatment mean values were $(52.57 \pm$ $15.36 \%, 104.5 \pm 17.54 \%, 38.42 \pm 15.08 \%, 57.13 \pm$ $19.26 \%$ respectively).

Table (3) shows results of the mean \pm SD values of group B for all measured variables $\left(\mathrm{FVC}, \mathrm{FEV}_{1}\right.$, $\mathrm{FEV}_{1} / \mathrm{FVC}, \mathrm{FEF}$ and MVV) the pre-treatment mean values were FVC $53.5 \pm 12.26 \%, 52.85 \pm 15.1 \%$, $103.14 \pm 18.59 \%, 30.5 \pm 14.8 \%$ and $47.08 \pm 16.26 \%$ ) while post-treatment was $65.72 \pm 11.13 \%, 68.41 \pm$ $10.39 \%, 110.63 \pm 11.89 \%, 52.91 \pm 16.11 \%$ and 56.87 $\pm 11.76 \%$.

\section{Comparison between groups post-treatment:}

Table (4) shows the mean \pm SD FVC posttreatment of group A was $53.14 \pm 12.76 \%$ and that of group B was $65.72 \pm 11.13 \%$. The mean \pm SD $\mathrm{FEV}_{1}$ post-treatment of group A was $52.57 \pm 15.36 \%$ and that of group B was $68.41 \pm 10.39 \%$. The mean \pm SD FEV $1 / F V C$ post-treatment of group A was $104.5 \pm 17.54 \%$ and that of group B was $110.63 \pm$ $11.89 \%$. The mean \pm SD PEF post-treatment of group A was $38.42 \pm 15.08 \%$ and that of group B was $52.91 \pm 16.11 \%$. The mean \pm SD MVV posttreatment of group A was $57.13 \pm 19.26 \%$ and that of group B was $56.87 \pm 11.76 \%$.

Table (1): Comparing the mean age, weight, height, and BMI of group A and B.

\begin{tabular}{|c|c|c|c|c|c|c|}
\hline Variable & $\begin{array}{l}\text { Group A } \\
X \pm S D\end{array}$ & $\begin{array}{l}\text { Group B } \\
\mathrm{X} \pm \mathrm{SD}\end{array}$ & MD & $\begin{array}{c}t- \\
\text { value }\end{array}$ & $\begin{array}{c}p- \\
\text { value }\end{array}$ & Significance \\
\hline Age (years) & $49.07 \pm 6.69$ & $50.28 \pm 6.62$ & -1.21 & -0.48 & 0.63 & NS \\
\hline Weight (kg) & $66.64 \pm 9.35$ & $68.57 \pm 6.44$ & -1.93 & -0.63 & 0.53 & NS \\
\hline Height $(\mathrm{cm})$ & $159.85 \pm 8.82$ & $163.07 \pm 6.62$ & -3.22 & -1.09 & 0.28 & NS \\
\hline BMI $\left(\mathrm{kg} / \mathrm{m}^{2}\right)$ & $25.93 \pm 2$ & $25.81 \pm 2.38$ & 0.12 & 0.13 & 0.89 & NS \\
\hline $\mathrm{FVC}(\%)$ & $47.07 \pm 16.37$ & $53.5 \pm 12.26$ & -6.43 & -1.17 & 0.25 & NS \\
\hline $\mathrm{FEV}_{1}(\%)$ & $44.85 \pm 15.98$ & $52.85 \pm 15.1$ & -8 & -1.36 & 0.18 & NS \\
\hline $\mathrm{FEV} 1 / \mathrm{FVC}(\%)$ & $100 \pm 17.72$ & $103.14 \pm 18.59$ & -3.14 & -0.45 & 0.65 & NS \\
\hline $\operatorname{PEF}(\%)$ & $29.78 \pm 12$ & $30.5 \pm 14.8$ & -0.72 & -0.14 & 0.88 & NS \\
\hline $\begin{array}{ll}\bar{X} & : \text { Mean. } \\
\text { SD } & : \text { Standard De } \\
\text { MD } & : \text { Mean Differ }\end{array}$ & & $\begin{array}{l}t \text {-valu } \\
p \text {-valu } \\
\text { NS }\end{array}$ & $\begin{array}{l}\text { Unpaire } \\
\text { Probabi } \\
\text { Non Sig }\end{array}$ & $\begin{array}{l}\text { value. } \\
\text { value. } \\
\text { cant. }\end{array}$ & & \\
\hline
\end{tabular}


Table (2): Comparison of pre and post-treatment means values of ventilatory functions of group A.

\begin{tabular}{llccl}
\hline & \multicolumn{4}{c}{ Group A } \\
\cline { 2 - 5 } & \multicolumn{1}{c}{ Pre } & $\begin{array}{c}\text { Post } \\
\text { X } \pm \text { SD }\end{array}$ & $\begin{array}{c}\text { X } \pm \text { SD } \\
\text { value }\end{array}$ & Sig. \\
\hline FVC (\%) & $47.07 \pm 16.37$ & $53.14 \pm 12.76$ & 0.004 & S \\
FEV $_{1}(\%)$ & $44.85 \pm 15.98$ & $52.57 \pm 15.36$ & 0.002 & S \\
FEV $_{1} /$ FVC $(\%)$ & $100 \pm 17.72$ & $104.5 \pm 17.54$ & 0.23 & NS \\
PEF (\%) & $29.78 \pm 12$ & $38.42 \pm 15.08$ & 0.004 & S \\
MVV (\%) & $48.65 \pm 18.53$ & $57.13 \pm 19.26$ & 0.004 & S \\
\hline
\end{tabular}

\begin{tabular}{ll}
\hline SD $:$ Standard Deviation. & S \\
NS $:$ Non Significant. & $p$-value : Probability value. \\
$\overline{\mathrm{X}}:$ Mean. &
\end{tabular}

Table (3): Comparison of pre and post-treatment means values of ventilatory functions of group $B$.

\begin{tabular}{|c|c|c|c|c|}
\hline & \multicolumn{4}{|c|}{ Group B } \\
\hline & $\begin{array}{c}\text { Pre } \\
\mathrm{X} \pm \mathrm{SD}\end{array}$ & $\begin{array}{c}\text { Post } \\
\mathrm{X} \pm \mathrm{SD}\end{array}$ & $\begin{array}{c}p- \\
\text { value }\end{array}$ & Sig. \\
\hline $\operatorname{FVC~}(\%)$ & $53.5 \pm 12.26$ & $65.75 \pm 11.13$ & 0.0001 & $S$ \\
\hline $\mathrm{FEV}_{1}(\%)$ & $52.85 \pm 15.1$ & $68.41 \pm 10.39$ & 0.0001 & $S$ \\
\hline $\mathrm{FEV}_{1} / \mathrm{FVC}(\%)$ & $103.14 \pm 18.59$ & $110.63 \pm 11.89$ & 0.13 & NS \\
\hline PEF (\%) & $30.5 \pm 14.8$ & $52.91 \pm 16.11$ & 0.0001 & $\mathrm{~S}$ \\
\hline $\operatorname{MVV}(\%)$ & $47.08 \pm 16.26$ & $56.87 \pm 11.76$ & 0.02 & $\mathrm{~S}$ \\
\hline $\begin{array}{l}\text { SD }: \text { Standard D } \\
\text { NS }: \text { Non Signifi } \\
\overline{\mathrm{X}}: \text { Mean. }\end{array}$ & & $\begin{array}{r}\text { : Significa } \\
\text { alue : Probabil }\end{array}$ & ity value. & \\
\hline
\end{tabular}

Table (4): Comparison of post-treatment mean values of ventilatory functions of group A and B.

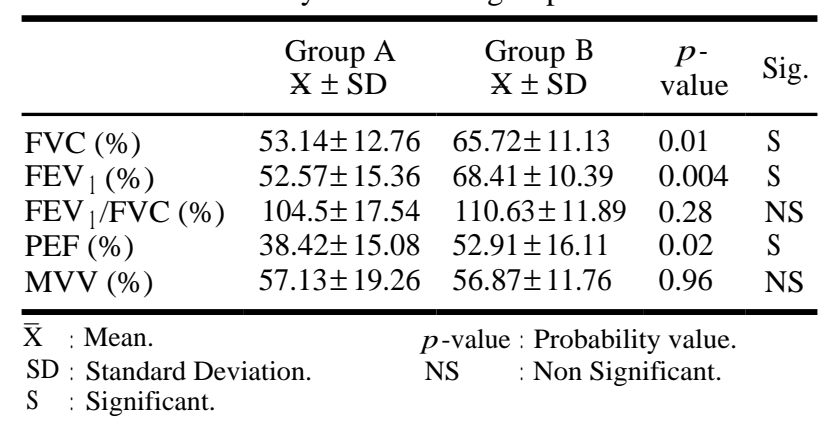

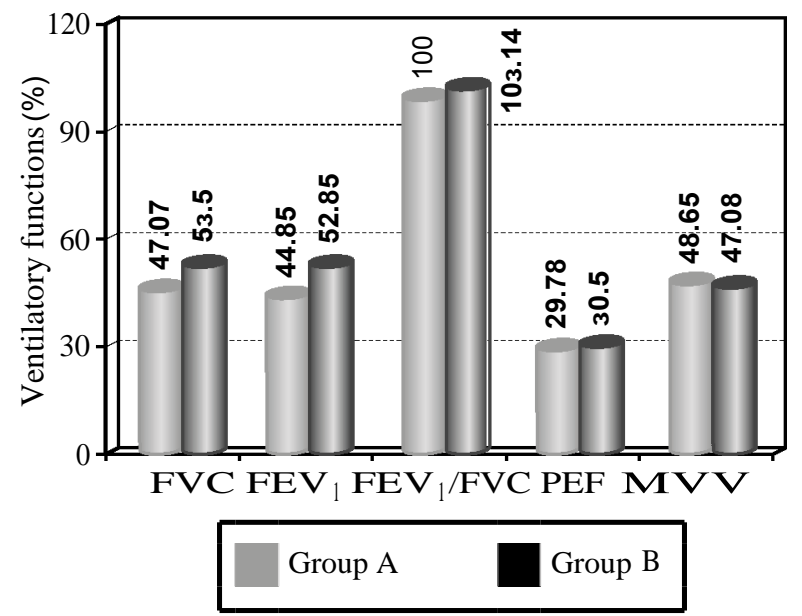

Fig. (1): Pre-treatment mean values of ventilatory functions of group $\mathrm{A}$ and $\mathrm{B}$.

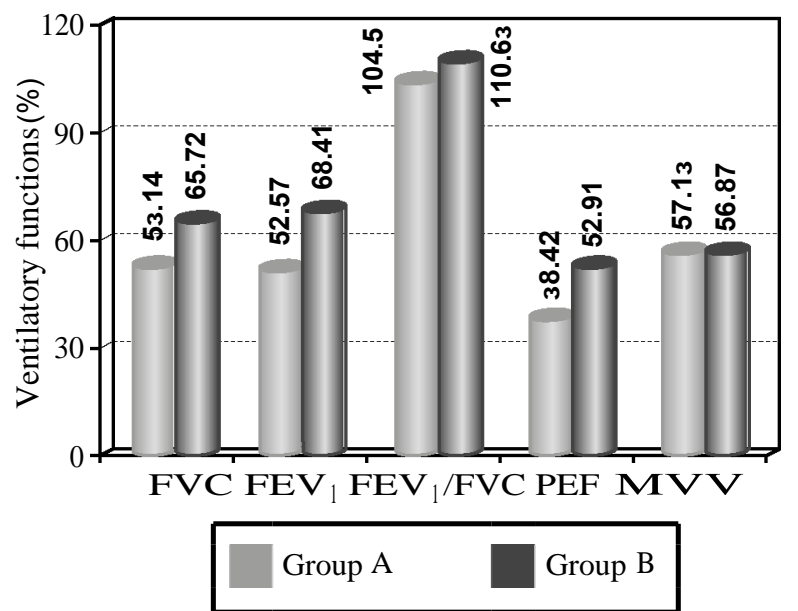

Fig. (2): Post-treatment mean values of ventilatory functions of group A and B.

\section{Discussion}

In the present study, the results showed that the inspiratory muscle trainer radically enhanced respiratory muscle strength and pulmonary functions regarding $\mathrm{FVC}, \mathrm{FEV}_{1}, \mathrm{PEF}$ and $\mathrm{MVV} \%$. These results coincided with results achieved by El-Sisi et al., who evaluated the effect of IMT versus Pranayama on pulmonary functions of hemodialysis patients, which further confirmed that IMT hadmore significant effectcompared to other techniques $\left(\mathrm{FVC}, \mathrm{FEV}_{1}, \mathrm{PEF}\right)(p$ was 0.0001*) [31].

Moreover, these results came in agreement with the results achieved by Felix et al., who assessed the effects of IMT in patients with Ataxia Telangiectasia, their results demonstrated a significant improvement of breathing, inspiratory muscle strength, respiratory volumes and Quality of Life (QOL) [32].

Furthermore, the results of Bahey El-Deen et al., showed significant improvement in respiratory muscle strength regarding PImax, and PE max by using pressure vacuum meter as well as improvement in pulmonary functions regarding $\mathrm{FVC} \%$, $\mathrm{FEV}_{1} \%$, and PEF\% with application of IMT during hemodialysis sessions for 12 weeks [33]

There is no documented data concerning the effect of combined aerobic training and IMT on pulmonary functions in hemodialysis patients, but Winkelmann et al., found that all exercise interventions significantly improved $\mathrm{FVC}, \mathrm{FEV}_{1}$, PEF, while MVV improved following aerobic training and aerobic training with IMT [34]

Also Enright et al., showed that this regimen of high-intensity IMT combined with aerobic training enhanced the inspiratory muscle function, 
induces morphological changes in the diaphragm, and increased lung capacities (FVC, FEV 1, FEV 1/ FVC and peak expiratory flow) in healthy subjects [35].

Dassios et al., stated that application of IMT and aerobic training for patients with cystic fibrosis resulted in a significant improvement in $\mathrm{VC}, \mathrm{FEV}$, and arterial oxygen saturation [36]. Also Shendy and Farag concluded that both IMT and aerobic training provided a significant improvement in the ventilatory functions due to increasing the respiratory muscles strength, efficiency and endurance [37].

Also El-Shemy et al., reported that leg pedaling for 30 to 40mins during the 1 st two hours of the dialysis session for 3 months improve musculoskeletal system, activity of daily living, circulatory, respiratory system and neurological system [27] .

In this study we found that group B who underwent IMT only showed a remarkable increase in FVC, FEV 1 , PEF than group A who underwent aerobic training combined with IMT. This could be attributed to the longer duration of combined training where most of the patients spent more than one hour (30mins for aerobic training and 30 mins for IMT, with 15 mins rest in-between). This caused early fatigability and exhaustion, which led to early termination of the session.

This was verified by Carvalho et al., who reported that hemodialysis patients have different features that contributes to a sedentary lifestyle, such as functional and structural alterations of skeletal muscles, uremia, inflammation, hyperparathyroidism, reduced secretion of testosterone, and malnutrition. Furthermore, the procedure of dialysis itself increases catabolism, which leads to a deterioration of the physical condition, which is the direct cause of limited exercise capacity among those patients [38].

From the above findings, it has been determined that the limited exercise capacity and early fatigability as well as presence of muscle cramps (due to decrease the blood calcium level) are the most common causes of early termination of aerobic training session in group (A). Therefore, it is recommended to conduct another study in which the aerobic training exercise can be applied intra dialytic while using inter dialytic IMT (in non dialytic days) to avoid the occurrence of fatigue.

\section{Conclusion:}

It was concluded that either a combined IMT with supervised program of aerobic training or
IMT alone for 12 weeks, both have significant improvement regarding pulmonary functions in hemodialysis patients, while it was more significant with IMT alone.

\section{References}

1- YOON S.H., CHOI N.W. and YUN S.R.: Pulmonary dysfunction is possibly a marker of malnutrition and inflammation but not mortality in patients with end-stage renal disease. Nephron. Clin. Pract., 111: c1-c6. [Medline] [CrossRef], 2009.

2- RAHGOSHAI R., RAHGOSHAI R., KHOSRAVIANI A., NASIRI A.A. and SOLOUKI M.: Acute effects of hemodialysis on pulmonary function in patients with endstage renal disease. Iran J. Kidney Dis., 4: 214-7, [Medline], 2010.

3- EL-ARBAGY A.R, YASSIN S.Y. and BOSHRA N.B.: Study of prevalence of end-stage renal disease in Assiut governorate, Upper Egypt. Menoufa Medical Journal, 29: 222-7, 2016.

4- REBOREDO M.M., HENRIQUE D.M., BASTOS M.G., et al.: Physical exercise in dialysis patient. Rev. Bras. Med. Esporte, 13: 427-30, [CrossRef], 2007.

5- COELHO D.M., CASTRO A.M., TAVARES H.A., et al.: Effects of a physical exercising program on conditioning of hemodialysis patients. J. Bras. Nefrol., 18: 121-7, 2006.

6- SCHARDONG T.J. and LUKRAFKA J.L.: Garcia VD Assess Pulm Funct Qual Life Patients Mainten Hemodial J. Bras. Nefrol., 30: 40-7, 2008.

7- FARIA R.S., SILVA V.S., REBOREDO M.M., et al.: Evaluation of the respiratory function, physical capacity and quality of life in patients with pre-dialysis chronic kidney disease. J. Bras. Nefrol., 30: 264-71, 2008.

8- KOVELIS D., PITTA F., PROBST V.S., et al.: Pulmonary function and respiratory muscle strength in chronic renal failure patients on hemodialysis. J. Bras. Pneumol., 34: 907-12, [Medline] [CrossRef], 2008.

9- JATOBÁ J.P., AMARO W.F., ANDRADE A.P., et al.: Assessment of the pulmonary function, respiratory muscular strength and six-minute walk test in chronic kidney disease patients on hemodialysis. J. Bras. Nefrol., 30: 280-7, 2008.

10- PAPPA M., DOUNOUSI E., DUNI A., et al.: Less known pathophysiological mechanisms of anemia in patients with diabetic nephropathy. Int. Urol. Nephrol., 47: 136572, [Medline] [CrossRef], 2015.

11- ABDALLA M.E., ABD EL-GAWAD M. and ALNAHAL A.: Evaluation of pulmonary function in renal transplant recipients and chronic renal failure patients undergoing maintenance hemodialysis. Egyptian Journal of Chest Diseases and Tuberculosis, 62 (1): 145-50, 2013.

12- RAJ D.S., ADENIYI O. and DOMINIC E.A.: Amino acid repletion does not decrease muscle protein catabolism during hemodialysis. Am. J. Physiol. Endcrinol. Met., 292: 1534-42, 2007.

13- IKIZLER T.A., PUPIM L.B. and BROUILLETTE J.R.: Hemodialysis stimulates muscle and whole body protein loss and alters substrate oxidation. Am. J. Physiol. Endocrinol. Metab., 282: 107-16, 2002. 
14- JOHANSEN K.L., SHUBERT T., DOYLE J., SOHER B., SAKKAS G.K. and KENT-BRAUN J.A.: Muscle atrophy in patients receiving hemodialysis: Effects on muscle strength, muscle quality, and physical function. Kidney Int., 63: 291-7, 2003.

15- KOSMADAKIS G.C., BEVINGTON A., SMITH A.C. et al.: Physical exercise in patients with severe kidney disease. Nephron. Clin. Pract., 115: c7-c16, 2010.

16- STORER T.W., CASABURI R., SAWELSON S. and KOPPLE J.D.: Endurance exercise training during haemodialysis improves strength, power, fatigability and physical performance in maintenance haemodialysis patients. Nephrol Dial Transplant, 20: 1429-37, 2005.

17- JOHANSEN K.: Exercise and chronic kidney disease: Current recommendations. Sports Med., 35: 485-99, 2005.

18- PAINTER P.: Physical functioning in end-stage renal disease patients: Update 2005. Hemodial Int., 9: 218-35, [PubMed], 2005.

19- AFSHAR R., SHEGARFY L., SHAVANDI N. and SANAVI S.: Effects of Aerobic Exercise and Resistance Training on Lipids Profiles and Inflammation Status in Patients on Maintenance Hemodialysis. Indian J. Nephrol., 20 (4): 185-9, 2010.

20- BRILLA L.R. and KAUFFMAN T.H.: Effect of Inspiratory Muscle Training and Core Exercise Training on Core Functional Tests Journal of Exercise Physiology online June 2014 Volume 17 Number 3, 2014.

21- PELLIZZARO C.O., THOMÉ F.S. and VERONESE F.V.: Effect of peripheral and respiratory muscle training on the functional. Ren. Fail., 35 (2): 189-97, 2013.

22- De MEDEIROS A.I.C., FUZARI H.K.B., RATTESA C., BRANDÃO D.C. and De MELO MARINHO P.É.: Inspiratory muscle training improves respiratory muscle strength, functional capacity and quality of life in patients with chronic kidney disease: A systematic review. J. Physiother., 63 (2): 76-83, 2017.

23- REBOREDO M.M., HENRIQUE D.M.N., FARIA R.S., CHAOUBAH A., BASTOS M.G. and PAULA R.B.: Exercise training during hemodialysis reduces blood pressure and increases physical functioning and quality of life. Artif. Organs., 34 (7): 586-93, 2010.

24- SOUZA R.B.: Maximum static respiratory prssure. J. Bras. Pneumol., 28: S155-S165, 2002.

25- PEREIRA C.A., SATO T. and RODRIGUES S.C.: New reference values for forced spirometry in white adults in Brazil. J. Bras. Pneumol., 33: 397-406. [Medline] [CrossRef], 2007.

26- BARREIRO T.J. and PERILLO I.: An approach to interpreting spirometry. Am. Fam. Physician, 69 (5): 110714. Medline, Google Scholar, 2004.

27- EL-SHEMY B.M., EL-KAZEH E.A. and EL-KUALLY R.: Efficacy of exercise program in intra hemodialysis on patients' Quality Of Life. Journal of nursing and health science (IOSR), Vol. 5, I (1), ver(IV): 17-30, 2016.
28- AL-RASHEDI S. and GHALEB A.M.: Effectiveness of Intradialytic Leg Exercise on Dialysis Efficacy among Patients Undergoing Hemodialysis. International Journal of Advance Research and Innovative Ideas in Education (IJARIIE), 3 (1): 133-44, 2017.

29- BAE Y.H., LEE S.M. and JO J.I.: Aerobic training during hemodialysis improves body composition, muscle function, physical performance, and quality of life in chronic kidney disease patients. Journal of Physical Therapy Science, 27 (5): 1445-9. Doi: 10.1589/jpts.27.1445, 2015.

30- GOSSELINK R., VAN DEN HEUVEL S.P., et al.: Impact of inspiratory muscle training in patients with COPD: what is the evidence? Eur. Respir. J., 37: 416-25, 2011.

31- ELSISI H., MAHMOUD M. and EL-KHASHAB S.: Training impact with inspiratory muscle trainer versus pranayama on pulmonary functions of hemodialysis patients, International Journal of Chem. Tech. Research, 10 (2): 417-24, 2017.

32- FELIX F., GIMENES A.C. and COSTA-CARVALHO B.T.: Effects of Inspiratory Muscle Training on Lung Volumes, Respiratory Muscle Strength, and Quality of Life in Patients With Ataxia Telangiectasia Pediatric Pulmonology, 49: 23 8-44, 2014.

33- BAHEY EL-DEEN H.A., ALANAZI F.S. and AHMED K.T.: Effects of inspiratory muscle training on pulmonary functions and muscle strength in sedentary hemodialysis patients. Journal of Physical Therapy Science, 30 (3): 424-7. http://doi.org/10.1589/jpts.30.424, 2018.

34- WINKLEMANN E.R., CHIAPPA G.R., LIMA C.O., et al.: Addition of inspiratory muscle training to aerobic training improves cardiorespiratory responses to exercise in patients with heart failure and inspiratory muscle weakness. Am. Heart J., 158: 768-75, 2009.

35- ENRIGHT S.J., UNNITHAN V.B., HEWARD C., WITHNALL L. and DAVIES D.H.: Effect of high-intensity inspiratory muscle training and combined with aerobic training on lung volumes, diaphragm thickness, and exercise capacity in subjects who Are healthy. Phys. Ther., 86: 345-54, 2006

36- DASSIOS T., KATELARI A. and DIMITRIOU G.: Aerobic exercise and respiratory muscle strength in patients with cystic fibrosis. Respiratory Medicine, May, 107 (5): 684 90, 2013.

37- SHENDY M. and FARAG A.: Ventilatory Response for Inspiratory Muscle Training versus Aerobic Training on Post Lung Decortication. International Journal of Therapies and Rehabilitation Research, [E-ISSN: 2278-0343] IJTRR, 4 (5): 265-75, 2015.

38- CARVALHO E.V., REBOREDO M.M., GOMES E.P., et al.: "Physical activity in daily life assessed by an accelerometer in kidney transplant recipients and hemodialysis patients," Transplantation Proceedings, Vol. 46, No. 6, pp. 1713-7, 2014. 


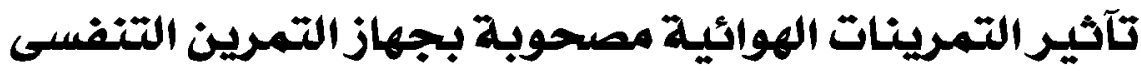

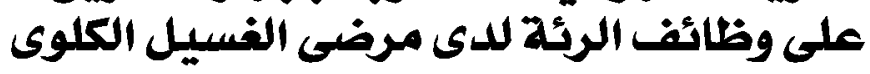

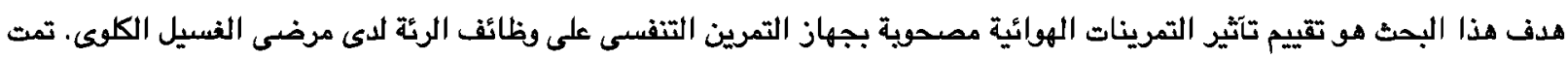

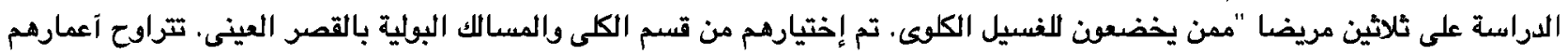

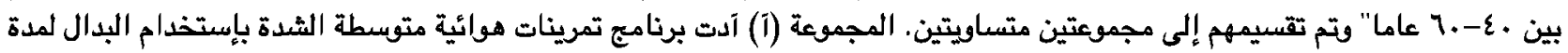

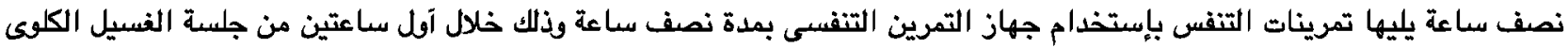

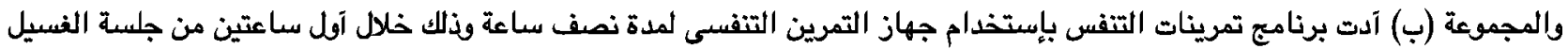

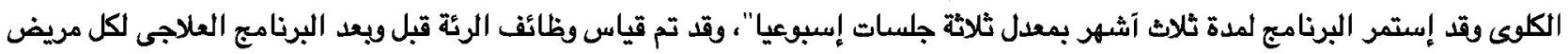

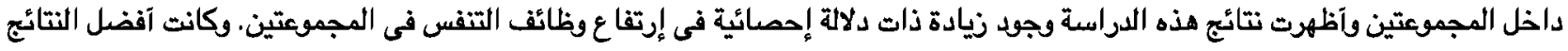



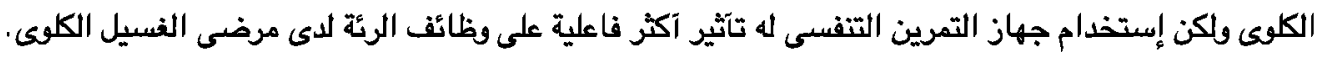

